\title{
The Role of Online Collaboration in Promoting ESL Writing
}

\author{
Jessie Wai-ching CHOI \\ Room 1208, HKU SPACE, 28 Wang Hoi Road, Kowloon Bay, Hong Kong
}

Tel: 852-3762-2281Ｅmail: jesschoi@yahoo.com

\begin{abstract}
The study examined an ESL writing class, which consisted of 36 students, at a community college of Hong Kong. The students took part in three online collaborative writing tasks by sending drafts to peers who gave them suggestions and comments for improvement and working together on the completion of the writing tasks via email.

The 36 students worked in small groups of four to six. They wrote, responded and revised using the email system offered by the WebCT interface of their course book. The results were evaluated by means of questionnaire, interview with participating students, report of the peer observer, written work, e-responses and reflective summaries of students.

The overall results suggest that students generally enjoyed the supportive atmosphere created by online collaborative tasks and regarded the use of online collaboration as a means of improving their writing by enhancing their motivation, awareness of the audience and the importance of revising, and by reducing their stress and cultivating their positive attitudes towards writing. The data show that the inclusion of the online component has potential in supporting learning and bringing about positive learning effects on writing as learners were found to enjoy the benefit of interacting with the other learners both in-class and out-of-class in the study.
\end{abstract}

Keywords: Peer writing, Online collaboration, E-learning, Online learning, ESL writing, Collaborative writing

\section{Introduction}

For decades, the use of information technology has been increasing in higher education and educational research has demonstrated that different ways of integrating the use of technology into classroom teaching have different effects on learning. In many cases, learning can be enhanced through the experience of a shared environment for discussing and working together. As an educational pedagogy that promotes learners' autonomy and improves their writing skills, online collaboration has the potential to promote students' learning (Curtis \& Lawson, 2001; Kaplan, 2002). This study therefore tries to explore the use of online collaborative writing in ESL writing classes with the students of a community college in Hong Kong. The underlining assumption of the study is that online collaboration can help improve students' writing skills by

- $\quad$ motivating them to write

- $\quad$ enhancing their sense of audience

- teaching them the importance of revision

- $\quad$ reducing stress in writing

- cultivating positive attitudes towards writing

Specifically, the purpose of the study is to find answers to the following questions:

1. Does online collaboration help improve students' writing? If so, does it help

1.1 motivate them in writing ?

1.2 increase their sense of audience?

1.3 teach them the importance of revision?

1.4 reduce their stress in writing?

1.5 cultivate positive attitudes towards writing?

2. Is peer help beneficial to the students' writing process?

3. What are the limitations of the use of online collaboration in the proposed context?

\section{What is Online Collaboration?}

Collaborative learning has a long historical tradition and has been studied for many years. Two strong advocates of 
collaborative learning are Piaget and Vygotsky, who point out that learners can learn better in an environment that encourages co-operation and interaction. A great deal of research has been done in this area and results have indicated that the collaborative process can result in better motivation, higher performance and better thinking skills (Johnson, Johnson \& Holubec, 1990; Bruffee, 1993; Slavin, 1996).

Along with the development of information and communications technology, the use of computers and the Internet has started to play an increasingly important role in education. Computer supported collaborative learning has become an innovation to improve teaching and learning (Järvelä, Hakkarainen, Lipponen \& Lehtinen, 2000). Previous research results generally show that learners are more willing to collaborate and are more capable of helping one another to achieve better results if they are allowed to engage in an online collaborative learning environment (Lee \& Chen, 2000; $\mathrm{Su}$, Chen, Chen \& Tsai, 2000).

\section{Why We Need Online Collaboration in the ESL Writing Context}

\subsection{Promoting Active Learning}

Collaboration may help to create new relationships in ESL writing classrooms. Unlike traditional classrooms where learners may be viewed as only the receivers of knowledge, learners can now have more control over their learning. Learner control means that the learner can take control of what, when and how he/she learns. This is a very easily perceived benefit of online learning. The benefits of learner control include an increased sense of personal responsibility for learning and a realization of individual differences, according to Ewing \& Miller (2002).

\subsection{Improving Writing Skills}

The rationale for using computers in ESL writing lessons is that good writing can be made possible by creating a sense of audience/community in writing, attaching importance to feedback and revision, reducing stress of writing and enhancing mutual help. It has been found that these aspects can be realized more easily via the use of technology because technology promotes collaboration and expands the learners' writing community, which in turn helps to make learners "more aware of the importance of audience in their writing, and gain more confidence as writers" (Cantrell, 2003). These aspects of the writing process are discussed in detail in the following sections.

\subsubsection{Cultivating a Sense of Audience}

In contrast to traditional ESL writing rooms where writing may be read/evaluated by the instructor only, the learners in an online writing classroom not only write for instructors, but also for peers and other people (if published). Learners can then experience real responses. Rather than writing for an unreal reader, they can now engage in real communication. The presence of potential online readers gives the learners a sense of audience in the writing process. They will realize the importance of taking into consideration the interests, needs and language level of their readers in the writing process. An environment that allows collaboration can therefore enhance the sense of audience among learners in the writing process.

\subsubsection{Enhancing the Importance of Feedback and Revision}

Having feedback is important to learners as it helps to "teach skills that help learners improve their writing proficiency" and produce written texts with fewer errors and more clarity (Williams, 2003). This can enhance learning and enable learners to improve their linguistic knowledge and understand more about the skills of writing as a result of receiving feedback; however, the common way for learners to get feedback seem to be from their teachers in the traditional writing classrooms. In fact, both recent research and practice have supported the use of peer feedback in ESL writing classes (Rollinson, 2005). Even a piece of good writing requires revision, which means that all learners need to rewrite their work (Chenoweth, 1987), a process in which the comments of others can be especially useful. Peer response can enhance the sense of/the need for revision and lead to better quality of work (Mendonça \& Johnson, 1994: p. 765).

\subsubsection{Reducing Stress of Writing and Promoting Mutual Help}

With the creation of a writing community in the online ESL classroom, learning may become more learner-centered and egalitarian, thus turning out to be less intimidating and more accessible. As a result, peers may be more inclined to work together in accomplishing tasks. Writing is especially appropriate in peer work because according to Morris (2001), learners "work more with each other in developing a shared product rather than listening as a group to the teacher or performing independently". And as writers, individuals may become less stressed as their peers provide assistance to them, thus reducing their sense of individual exposure. The writing community can also help to cultivate the sense of interdependence, which encourages learners to engage in the community and help one another in the writing and revising process.

\subsection{Developing Higher Order Thinking Skills}

Higher order thinking is a way to approach problem solving and to think critically (Bloom, 1956). The ability to think critically is essential if individuals are to live, work, and function effectively in our current and changing society. 
Research has shown that technology applications can support higher-order thinking by engaging students in authentic, complex tasks within collaborative learning contexts" (Valdez, 2005). Different kinds of technology may help to develop different kinds of higher-ordering skills. Email and all sorts of discussion forums promote reading, writing, criticizing and problem-solving skills; Internet searching promotes learners' reading, researching, exploring, inventing and thinking skills; word-processing promotes writing, organization, analyzing and inventing skills.

\subsection{Enhancing Interactivity}

Online collaborative writing provides an opportunity for the exchange of ideas and views. Writing is an information-sharing process by means of which learners can shape their opinions based on the comments of others. Moreover, since learners have to give comments on others' work, the more responses they make, the more they will be aware of the importance of the use of language in writing, as online communication relies almost entirely on a written format. The use of technology could encourage discussion about writing since computer communication can be done either synchronously or asynchronously. These modes allow learners to have more chances to engage in discussing others' work and helping one another to improve their work. Their writing becomes a response to discussion that will stimulate further discussion. The creation of "responsive and active learning environments" (Cicognani, 2000; Hannafin \& Hill, 2002, p.77) leads to an improvement of learning effectiveness of this group of students since online collaboration pedagogy utilizes peer help in constructing knowledge (Xun, Yamashiro \& Lee, 2000; Andrewartha \& Wilmot, 2001).

\section{Research Review of the Use of Online Collaboration in ESL Writing}

\subsection{Studies on the Benefits of Online Collaboration}

Numerous studies have been carried out in an attempt to discover whether students with online collaboration opportunities learned better than students with traditional methods in ESL writing lessons. The use of online collaboration has focused largely on bringing about changes in student writers' attitudes and on writing resulting from the use of information technology tools, such as email. Most of these studies have documented a number of favorable impacts on the use of online collaboration in the ESL writing context, including increased audience awareness, motivation and willingness to make revision.

For instance, Caroline Ho's 2000 study, "Developing Intercultural Awareness and Writing Skills through Email Exchange", examined the use of online collaboration in a writing project between primary level pupils from two schools, one in Singapore and one in Birmingham (UK). Her study shows that the use of online collaboration has helped to "develop pupil's confidence, language skills, creativity and sense of awareness of intercultural concerns". Moreover, students are found to be more motivated and positive towards writing.

Another study conducted by Jor (2000) with a group of Hong Kong university students was used to examine the effectiveness of online collaboration in developing students' English proficiency, competence and confidence. The researcher used both quantitative and qualitative methods in measuring the course effectiveness, and the results showed that there was a modest increase in the writing scores of the students after they had participated in the course. In addition, the students generally welcomed the use of collaboration and the increase of interactivity in the writing process.

Roseanne Greenfield, in her 2003 article "Collaborative E-mail Exchange for Teaching Secondary ESL: A Case Study in Hong Kong", points out that the majority of the participants in her study "made significant progress in writing, thinking and speaking" through the exchange. Both the qualitative and quantitative data showed students' positive responses towards the use of collaborative writing model and the possibility of using collaborative exchanges in enhancing second language learning.

Esnawy (2004) used both in-class and online instruction modes in a writing course for graduate students in an academic writing class at the American University in Cairo. The student comments on the use of email for submitting their essays and communicating with the teacher and other students were found to be very positive, and the researcher pointed out that combining in-class and online instruction was beneficial for the students as there was more interaction both in-class and out of class, thus enhancing students' learning experience.

\subsection{Studies on Peer Feedback and Response}

A second area of research has explored the usefulness and patterns of peer feedback and response in the ESL writing context, both within a class and between students in different classes. Although most of the research shows that students enjoyed the process of interaction, some of them did not find peer feedback and response useful or helpful (Tsui $\& \mathrm{Ng}$, 2000; Berkow, 2001; Ferris, 2003).

In assessing students' responses in the use of both online and face-to-face responses, DiGiovanni \& Nagaswami (2001) conducted a study in two pre-college ESL writing classes at a Community College in Philadelphia. The results of the study showed that students found the peer review process useful. They welcomed the use of both face-to-face and 
online peer review, and the researchers agreed that frequent online interaction could help students become more critical and effective negotiators. The researchers also found that "computer conversations are a form of hybrid communication that allows students to respond spontaneously, yet offers them the opportunity to reflect on their ideas, rehearse their responses, and respond at their own pace" (p. 269).

In a similar vein, Tuzi (2004) studied the use of peer comments as an aid to revision in writing among 20 ESL learners in a college in Pennsylvania. The results showed that students preferred face-to-face feedback to online feedback, though they found that online feedback was useful in revision. In addition, Tuzi found that the training students received before the writing process was useful in enabling them to be more effective responders and to be more aware of some of the areas of concern in writing and giving feedback.

\section{Design of the Study}

\subsection{Setting}

The study was conducted with a class of 36 higher diploma (intermediate level) students (28 females, 8 males) from a community college in Hong Kong in the second semester of 2004-2005. The participants were registered for the business English module. The instructor was the researcher of this study and an experienced teacher who taught students of the same level was invited to be the observer. The study attempted to collect students' feelings and attitudes towards the use of online collaboration in the ESL writing lessons, so there was no inclusion of a control group.

The students and the instructor met in their regular face-to-face English lessons every week for three hours, in which they were taught the regular curriculum of the College (Business English). However, the writing module was changed into a hybrid format for this study for fourteen weeks: a mixture of classroom teaching and web-based activities. The participants were divided into groups of four to six according to their own choice.

\subsection{Tasks}

There were three writing tasks in total for the students throughout the semester. Face-to-face lessons on the basics of the writing genres of the tasks, related language items and criteria for good writing were given prior to the start of the online writing process, with the use of an email system provided by the students' course book "Business Communication" (Krizan, Merrier \& Jones, 2005).

\subsubsection{Writing a Short Report}

The design of Task 1 was to familiarize students with the operation of the online writing process used in this study. A simulated task related to the writing of short reports for a particular person of a group was given. The students were asked to finish a short and informal report individually for the Marketing and Managing Manager of their college, summarizing the views of higher diploma students (who were their schoolmates) on the effectiveness of the learning facilities and environment in the community college. To make the writing task authentic, the students had to collect real data by carrying out a small survey interviewing at least ten students of the College on their views on the topic before compiling their report. The students were then required to send their first draft to at least two of their group members for comments (they were mostly in groups of five). All email messages had to be copied to the instructor, so that she could monitor the comments students made and their progress. The final output was a result of the collaborative work of the student writer and the comments of his/her peers.

\subsubsection{Writing Minutes}

The purpose of Task 2 was to familiarize students with the concept of the use of online collaboration and to provide them an opportunity to apply the principles and skills acquired in the previous task. The writing approach taken for this task was therefore truly collaborative as students worked together to complete a writing task.

In this task, students were asked to work in their groups and plan for a face-to-face meeting to discuss the issues relating to the organization of the opening ceremony for the Third International Student Conference which would be held in Hong Kong. They had to take the roles of the members of the organizing committee of the conference who were representing different sectors, like students or the government. They had to conduct the meeting (for about 20 minutes) in front of the instructor and one observer group consisting of four to six of their classmates (chosen randomly from the class). The observer group needed to take notes of the meeting they attended. After the meeting, each member had to submit the main points they noted down to their group members by email. Each of them had to comment on the points given by others. Then the leader allocated each member the responsibility for writing up a draft for part of the minutes in form of a paragraph, which they had to send to their group for comments. Based on the comments of group members, the writer of the particular sections could make amendments, and the final drafts were then forwarded to the leader for compilation. The final work was sent to members for comment once again, before being submitted to the instructor. Finally the instructor gave comments and a grade.

\subsubsection{Writing a Long Report}


After the students had established a familiarity with the online learning process from the first two tasks, Task 3 provided an opportunity to consolidate their skills in the use of online collaboration in ESL writing. In Task 3, the students were asked to produce a formal report for the government of Hong Kong in the capacity of a consultancy group on the views of the public relating to the "Concept Plan of Lantau", a development plan proposed by the government for Lantau Island (an outlying island of Hong Kong). Each group had to interview at least 30 Hong Kong citizens or tourists. The report was also more complete in its format since the students had to include an abstract and sections dealing with implications and conclusions.

\subsection{Data Collection}

Taking into account the time and financial resources available, survey questionnaires were used in eliciting data regarding the research objective. In addition, in order to capture the various perceptions that may exist among students in the use of online collaboration in writing classes and to verify the responses from the questionnaires, a mixture of qualitative data collection techniques was used in the study: students' reflective summaries, interview scripts, observer notes, students' written work and online responses. The students' post-course questionnaire survey findings, interview scripts and students' reflective summaries were used mainly to collect data that tell if online collaboration helped improve their writing and peer help was beneficial to their writing process. To assure the trustworthiness of the findings, a triangulation of various forms of data (instructor's reflective summaries and observer notes) were employed to allow cross-checking of data and interpretations from different sources and explore ways of better structuring the online writing lessons. A further way to promote trustworthiness was to use the participants' written work and peer responses to verify the data and check if the interpretations are reasonable.

\subsection{Data Analysis}

For the purpose of this study, the data originating from the above sources were collected at different stages. As a first step, the responses to the post-course questionnaire (Appendix) were organised and transformed into percentages and mean scores. The next step was transcribing the interview tape. Then the interview transcript, the observer report, the reflective summaries from students and the instructor were read so as to develop ideas about categories and relationships relevant to the research questions. The final step was to analyse the written work of student writers by comparing the drafts and the revisions and evaluate peer feedback by identifying the changes student writers made based on peer feedback.

\section{Discussion of Findings}

\subsection{Introduction}

Among the 34 respondents (two of the participants were absent on the day of evaluation), the male and female distribution was $25 \%$ male, $75 \%$ female. Since the difference between data obtained from the male and female respondents is insignificant, they are reported as a single group. For easy reference, the data from these sources are identified by a code representing the sources $(\mathrm{Q}=$ questionnaire, $\mathrm{I}=$ interview; $\mathrm{R}=\mathrm{reflective}$ summaries and $\mathrm{E}=\mathrm{e}$-feedback). The task number is also given (T1, T2, T3) when the data are taken from reflective summaries or e-feedback. As for data from interview scripts and the questionnaire, no task number is given since students' comments for the three tasks in these sources were mixed together. When the data from an individual student are used, they are reproduced in the participants' own unedited words with an identifying number (S1, S2, etc.). Thus R-T3-S6 indicates data obtained from Student 6 in relation to Task 3 in the reflective summaries. In addition to these data sources, observations of the instructor cum researcher were embedded in the discussions of the research questions.

\subsection{The Usefulness of Online Collaboration in the ESL Writing Process}

The positive effects of using online collaboration in ESL writing lessons can be found in the following aspects:

- increase in motivation

- enhancement of sense of audience

- promotion of importance of revision

- $\quad$ reduction of stress in writing

- cultivation of positive attitudes towards writing

\subsubsection{Increase in Motivation}

Firstly, the data from the post-course questionnaire showed that online collaboration could help motivate students to learn from their peers; however, the students did not perceive that online collaboration was very helpful in motivating their interest in writing, especially when they had to deal with a task that required a longer period of time to finish or more complicated procedures. This is reflected in the students' comments from the reflective summaries they made after finishing each writing task. Significant differences in their motivation to learn could be found in the responses of some of the students made for Task 1 (Short report) and Task 3 (Long Report). 
Though the genre of writing was the same, Task 3 was comparatively longer and more complicated; thus students were expected to spend more time on it and were involved in more procedures, for instance, they had to make a questionnaire, go out to carry out interviews and conduct analysis. In addition, in the process of completing Task 3 , students had to collaborate with others by contributing to all parts of the report, commenting on others' work and making revisions based on peer feedback.

Task 1 was shorter and simpler as students were required to complete a very short questionnaire, conduct an interview with 10 people, complete a 500-600 word report on the own, send it to other group members for comments and then revise it based on peer responses.

The responses given by three students in the reflective summaries for Task 1 contrast markedly with those they gave for Task 3. This can be illustrated by the comments some of the students made for the two tasks: (See Table 1)

The comments they made coincide with the findings from the post-course questionnaire that the respondents regarded online collaboration more helpful in encouraging learning from peers than to writing.

\subsubsection{Enhancement of Sense of Audience}

As shown by the findings of the questionnaire, another benefit of online collaboration on writing is that students generally become more aware of the importance of audience awareness after engaging in the course. The percentage may not be high enough to prove that there was a significant change among the students; however, it can be sufficient to prove that there was a change of attitudes among students.

In the present study, students were provided with an environment where they could get a larger and more varied audience to read their work and they knew that this audience would provide feedback on how their work could be improved. In addition, they could become the audience for their peers. This kind of environment has gradually cultivated a sense of audience among students in their writing process, which they found beneficial. According to Bloch (2004), "the internet allowed these writers to receive comments from a real audience with a real purpose but without the artificial constraints of a face-to-face classroom....." As one of the students reported in the reflective summary:

As audiences are my classmates, which are at the same level as mine. Therefore comments given by them will be useful in helping me to improve my writing skills. (R-T1-S16)

The cultivation of sense of audience among students in their collaborative writing process was regarded by the peer observer of this study as a feature of the pedagogy of the online writing course, as she said in her report:

Through the process of collaborative evaluation and writing, students can become more aware of a sense of audience.

Nevertheless, there were students who still regarded the teacher as the real audience that could give grades and marks (as revealed in the interview). It is probably due to the authoritarian role of the teacher that persists in Chinese classrooms. This coincides with the finding of Anderson (2002), who pointed out that teacher feedback to second language writers is often regarded as the most important.

\subsubsection{Promotion of Importance of Revision}

The positive response students made to the question that asked if online collaboration could help them be aware of the importance of revision in the writing process demonstrates that most of them (mean: 3.69) realized the need to revise within the writing process and looked upon this practice as a good way of improving their writing. The interview and the reflective summaries show that some students found that revision was useful to the improvement of their writing and that they liked doing it. One of the students put the following in her reflective summary:

As I need to give out my first and second draft for comments, this gives me a chance to make amendments on my work before giving out the final draft. Therefore I prefer this learning format to the traditional one. (R-T1-S16)

Another student in the interview also regarded revising as helpful to improve her writing skills. The reason was:

We got more chances to revise our work as we need to finish many drafts and make changes according to others' comments. (I-S6)

As students tend to make revisions in their work in the writing process, they may take more responsibility for their own learning, thus allowing them to be more independent of the teacher inside and outside of the classroom. This training process may widen the horizon of the students and empower them to be more autonomous in their future learning, as illustrated in the report of the peer observer of this study:

Besides increasing their sense of audience, online collaboration has enabled students to be more responsible writers.

\subsubsection{Reduction of Stress in Writing}

It was observed that in this e-learning environment where students could take responsibility for their own learning and benefit from a supportive network with collaboration and co-operation provided, most of the students $(\mathrm{m}=3.69)$ found that they became less stressed in their writing process. 
With the emergence of a learning community created by online collaboration in this study, students could learn from one another, share their ideas and work together towards common goals. There was collaboration and communication, not competition and isolation anymore. The comments of students in the questionnaire indicate that they liked the online learning mode more than the traditional one since they found it "more interesting" and could get the "comments from peers" in the process. This view is consistent with the findings of Mabrito and Self, as reported by Tannacito (2001), who point out that online learning platform could help provide a "non-threatening" and "reduced-risk" environment for student writers.

\subsubsection{Cultivation of Positive Attitudes towards Writing}

When the students were asked in the questionnaire, most of them stated that they enjoyed the online writing lessons more than traditional ones and that they liked doing the writing tasks online. This finding corresponds with the analysis in the previous section. In addition to the benefits of being more interesting and getting comments from peers, the majority of students appreciated the "convenience" given by the online learning mode. As one of the students commented in their reflective summaries:

Submitting works online is very convenient, and I can get the responses from group mates immediately. Therefore I think this format of learning is very efficient and can save time. (R-T1-S16)

Other reasons given by the students in support of the use of the online learning mode included the flexibility allowed for students in the writing process. According to the comments from the interview, the flexibility could be found in the time given for completing the tasks and the technical help available for them to complete their work. As one of the students in the interview reported:

Online writing is better as in the traditional lessons we have to finish the tasks within a short time. We are constrained by time and the quality of writing will be affected. (I-S3)

It is, however, noteworthy that some of the students did not think that their writing skills had been improved using the online writing course or that they had learnt to be an effective writer in this course. This may largely due to the lack of timely responses from their peers and quality of comments they received in their group, as observed by one student in the interview:

[Online collaboration is] not very useful in helping us to improve the writing skills. It would be more useful if we could work with someone who was of higher standard...(I-S1)

As pointed out by the peer observer of the study in her report, "students sometimes experience difficulty deciding on the validity or relevance of peer comments", thus reducing their confidence on the effectiveness of online collaboration in improving their writing skills or helping them to be effective writers. It is true that not many peers could produce useful comments as this was the first time that they tried online collaborative writing tasks, but as Rollinson (2005) states, "by giving students practice in becoming critical readers, we are at the same time helping them towards becoming more self-reliant writers, who are self-critical and who have the skills to self-edit and revise their writing" (p. 29).

\subsection{The Usefulness of Peer Help in the ESL Online Writing Process}

In confirmation of the results of the previous sections on the usefulness of using peer help, the findings of the quantitative and qualitative analysis of students' revisions and e-feedback in the writing process are further discussed here.

\subsubsection{Changes on Revisions Based on E-feedback}

Most of the changes students made on their drafts based on peer feedback were on making meanings clearer and adding new information. For instance:

Making meanings clearer

"it would be better if you can include the name of the person who suggest the ideas....." (E-T2-S1)

\section{Adding new information}

"If you can point out what is their final decision may be better." (E-T2-S1)

In addition, it seems that e-feedback had a greater impact on student writers' revisions in Task 1 (n: 17) than in Tasks 2 (n: 3 ) and 3 (n: 0). This may probably due to the differences in the nature and writing process of the tasks. Since Task 1 was an individual task and the operation process was comparatively simpler than the other group writing tasks, students might find it easier to give comments to their peers and to act on those they received in the group writing tasks. Another interesting observation is that e-feedback was given primarily on the initial drafts and the subsequent drafts received fewer comments. This could be due to the misconception of students that peer comments were more useful for the first drafts or the limitation of time in the middle and later stages of the collaborative writing process in Tasks 2 and 3 . With respect to the message components of peers, despite the fact that more than $50 \%$ of the response components written by 
peers were found unhelpful to the improvement of the drafts (as 43\% consisted of praise and 11.5\% of useless comments), the findings did show that the student writers had given more comments on the macro level problems, such as the improvement of content or the development of ideas (as 24.9\% and $15.8 \%$ were respectively about advice or making changes to the content or ideas and criticism on the content and ideas of the drafts), rather than on the micro level problem like the change of grammar). Examples of the message components on advice or suggestions and criticism are as follows:

Advice or suggestions

"It is more clearly to specify the result by using the percentage." (E-T1-S7)

\section{Criticism}

"you forgot to add your name and position at the end of the report." (E-T1-S4)

The above finding did show that the training student writers received on giving comments before the commencement of the writing tasks had some influence on them though it was unable to prove that the students had been trained to give quality feedback, since they still produced a lot of unhelpful comments.

\subsubsection{Changes on Revisions Based on Members' Drafts}

In Tasks 2 and 3, student writers had to work collaboratively as each one was responsible for writing a particular section. Hence, they needed to make amendments to their drafts based on the information of members' drafts besides making changes to their own drafts based on peer feedback. They had to select useful pieces of information from members' drafts since some of it might be either incorrect or not necessary. The results of quantitative analysis of student revisions based on the information of members' drafts show that most of the students (especially in Task 3) made very little or no change to their drafts after reading others' work. This may be due to the fact that they did not trust their peer work or had no time to refer or select the useful materials form their peers' work. However, it is interesting to note that the revisions that most of the students made based on the information of peers' drafts were on adding new information (73\%). For instance, in Task 3, one of the student writers added in the information of the interviewees after getting the relevant information from her group member. Most of the new additions to the work were found suitable and helpful in the improvement of the work by giving more detailed information.

\subsubsection{Usefulness of Peer Help on Student Writers' Writing Process}

Though we could find some negative comments expressed by the students on the use of online collaboration, particularly peer help, as mentioned in the previous section, most of the students' reflective summaries and responses from the questionnaire and interview shared one common feature: they spoke highly of peer help. This is also reflected by one student in the reflective summary:

I can get the comment of my writing exercises from my group mates. After I have received the comment, I can improve my work before I send to the tutor. Getting the comment from my group mates can let me know more ideas of my work also. (R-T1-S36)

However, an interesting finding was that the responses students gave to three similar statements regarding peer feedback or comments in the questionnaire was somewhat different: (See Table 2)

Though students rated highly the usefulness of peer responses to their correction of work and improvement of writing skills, the findings suggest that some of the respondents became uncertain about the effectiveness of peer feedback/comments when they were asked to make the evaluation again. This may reflect the fact that some of the respondents were still unsure about the effectiveness of peer responses, and this may explain why $15 \%$ of them switched to "neutral/certain" when asked for their opinions again (\#C). Their uncertainty or ambiguity may stem from their "difficulties deciding on the validity or relevance of peer comments" as pointed by the peer observer of this study. On one hand, they seemed to have received a lot of comments from peers; on the other hand, they were not sure about their validity, so they tended not to adopt them for use in their work. Comment of students from the interview and reflective summaries can best explain this phenomenon:

I usually got positive comments-the good ones-not really the helpful ones. (I-S3)

I'm not sure whether what I 'learnt' from group mate is correct or not. I find no direction in learning from others' work. (R-T1-S23)

Despite the contradictory comments regarding the effectiveness of peer responses shown above, the results of the questionnaire survey appear to support the view that students in general had favorable perceptions of peer help. It seems that they enjoyed the interaction between them and peers during the writing process and this helped create a positive attitude towards writing (Rizk, 2001). As Crank (2002) states, "in the process of guiding them to online peer response, we activate their learning, calling upon them to demonstrate and trust their innate and their recently acquired standards for good writing". We may therefore conclude that peer help is beneficial in the writing process since it generated more 
interaction between peers, thus enabling the development of positive attitudes towards writing.

\subsection{Limitations of the Online ESL Writing Course}

On the whole, most of the students in this study found the course design helpful and enjoyed the use of online collaboration and peer help in their writing lessons; however, there are some areas in which the use of online collaboration and peer help are found not very effective, according to the comments of students from the interview, questionnaires and reflective summaries.

\subsubsection{Task Setting}

An interesting result of the study is the comparatively low ratings for Task 3 in terms of the time allowed for completion and the appropriateness to their level. This might suggest that a more careful re-design of the task. In addition, the low ratings to the statements that asked if the students felt comfortable taking part in the group writing tasks and if it was easier to discuss tasks online than face-to-face might be related to the dissatisfaction of some of the students with Task 3.

Moreover, it was found that students favored a task that was simple in its design. As reflected from the reflective summaries, Task 1 (short report) received more positive comments than Tasks 2-3 (minutes and long report) generally. Since Task 1 required students only to finish the short report on their own and then revise their work once based on the comments of peers, it was comparatively simpler than Tasks 2-3 in which students were required to produce more drafts and make more comments. Coupled with the tight work schedule and the uncooperative attitudes of peers, a student voiced his/her preference for Task 1 in the interview:

I like the way we did the 'Short Report' since I didn't need to co-operate with others to finish my work and I could get their comments after I finished my work. I don't like the way we did the 'Minutes' and the 'Long Report' as one member failed to submit the work on time, the whole group would be affected. (I-S2)

\subsubsection{Technological Use}

When evaluating the technological component of the online writing course (the use of email system of the WebCT), some of the students praised the use of email for submitting their essays and communicating with each other. As one of the students reported in the interview:

The most useful aspect to me is the email system because it is efficient, which is much better than the Yahoo. It is quick to upload the document. (I-S5)

However, there were also students who criticized in the interview on the email system provided by the WebCT:

It was troublesome to select the names of group members out from the long list given. (I-S5)

The sending or receiving time shown in the messages is not about the local time, it is about the US time. (I-S2)

As revealed above, the shortcoming of the email system of the WebCT is that students could not create a group distribution list that they could use for dispatch. Every time when students sent their work to their group members, they needed to select the names out from the long list that included the names of the students from the six English classes the instructor taught. This procedure had to be repeated when students sent out their work for comments or compilation.

\subsubsection{Group Dynamic}

A major goal of the online writing course was to provide students with the opportunities to construct knowledge when working together in groups. In this study, students were allowed to form their own groupings with the group size set at 4-6. The result was that seven mixed-ability groups of four to six were formed to work on the three writing tasks collaboratively. It is, however, interesting to note that some high-ability students reflected in the reflective summaries and interview that they thought their peers were not very helpful in assisting them in improving or completing their work. They found that the comments and ideas of their peers were either "not correct" or "not useful". They even worried that their performance would be undermined by their group members since they would receive the same grade or marks, as mentioned in one of their reflective summaries:

$\ldots$ if the comments of the group members are not correct, it will affect the overall grade of an individual's work. (R-T1-S14)

The lack of useful peer feedback from group members may account for some students' negative feelings towards the use of online collaboration and peer help in the writing lessons.

\subsubsection{Peer Help}

An important feature examined in the previous section was the usefulness of peer help in the online writing process. As indicated in the findings, the value of peers lies in their supportive function rather than as critical readers of each other's texts. As one student mentioned the following in the reflective summary when asked about the most useful aspect of the course: 
I would like to say that it is really happy to work with my group members. (R-T3-S35)

The major problem of peer help identified by students is that the peer feedback was of limited use. The students of the study (particularly the higher ability ones) regarded their peers as failing to make useful comments/ideas on their work. For example, two students commented in the interview:

As some of the group mates pointed out, even they themselves were not sure about the reliability of their comments when they sent out to me. (I-S1)

Some of the comments are very general, ... not very helpful for improving the work ... (I-S4)

In addition, although the tasks were designed to ensure that there was equality of participation in the sense that all students had an equal chance of participating in the discussion in their groups, the findings show that some of them did not actively join the activities. Nor did they observe the deadline for submitting comments or their contributions to the work. This not only affected the progress of the whole group, it also defeated the objective of the course in which all of the students were expected to collaborate and contribute ideas to help one another. This phenomenon was recorded by a student in the reflective summary:

But the progress may be out of control if one of the member didn't co-operate. As a result, I can't complete the task---a bit stressed as I did hard in my group's task. (R-T2-S23)

\subsubsection{Teacher's Role}

The course design was intended to let the instructor take a less prominent role during the discussion among students. It was hoped that more space could then be created for students' voices by doing so. Within this context, the students could feel that their discussion was of value and that they could share ideas and create meanings collaboratively.

However, the teacher-student relationship shown in the study seems to be indicative of Confucianism which values the teacher as the sage and the repository of knowledge. It is not surprising to find that only $59.4 \%$ of the respondents (mean=3.69) from the post-course questionnaire survey considered the support from the instructor was sufficient. The following direct quotes from students' post-course questionnaire are representative of the general responses when they were asked about the improvements for the course:

The teacher should be more interactive with students. (Q-S8)

The teachers give comments to our works. (Q-S10)

Lecturer can give comment before finalize the whole report. (Q-S24)

Miss can give comments to us before I send the final draft. (Q-S34)

It is obvious that the participants in this study felt a sense of uncertainty without the instructor's comments on their work as there is a tendency among ESL students in Hong Kong to wait for the teacher for guidelines or comments on their work. The evaluation shows that they appear not to trust their peers' comments and want more input from the teacher. This was also pointed out by the peer observer of the study:

Tutor gives comments and grades students at the final stage. This approach can train students to think independently and be more critical when evaluating peer comments. However, the overall quality of interaction in the course might be compromised.

\section{Implications and recommendations}

The current study shows how students engaged in an online writing environment reacted differently from the way expected in a traditional one. Since it was the first time for them and the instructor to participate in the online learning and teaching mode, the weaknesses displayed were unavoidable. Therefore, other researchers or educators need to take into consideration the limitations identified in the study if they would like to have an effective implementation of the online collaborative learning in their future ESL writing lessons.

Firstly, more training and practices on how to give and receive the most useful comments needs to be provided prior to the start of the writing tasks. During the current study, it is found that some of the students were passive and unwilling to give their comments, and did not provide responses at the required time. Even worst, the study shows that some of them did not know how to give comments though they had been given guidelines or briefings before the start of the tasks. In that case, their group members had to suffer as they could not have the useful comments of their peers for improving or collating their work. This has greatly undermined the effectiveness of online collaboration.

In improving the communicative responsibility of students, students should be made more aware of the issue of time management. Also, even if they gave comments, they tended to give some very general ones or just focus on the aspect of grammar. This may be due to the lack of former experience in doing the writing tasks in the online mode. It is, therefore, proposed that a more complete and thorough training program aiming at equipping the students with the skills of giving effective comments be given prior to the implementation of the course. As the peer observer of the study 
suggested in her report, "students can then learn what to look for when reviewing others' drafts and how they can make their comments more concrete". Training students can help them be more effective responders and highlight the areas that they need to be concerned when writing and responding.

Secondly, the assistance of the instructor should be enhanced in the writing process of students as students commented in the questionnaire, interview and reflective summaries showed that some of the students felt that there should be more of teacher's assistance in the writing process. The assistance here means the feedback to their work. This is a reflection of the students' long-held traditional belief of the role of teacher as the only repository of knowledge. It is important that the concern of the students in this aspect be addressed in order to enhance the effectiveness of online collaboration. This is agreed by the peer observer of the study who suggested in her report that "the tutor can consider providing feedback to students at an earlier stage before their final submission". Nevertheless, the instructor should remember that the amount of his/her intervention in the group learning process should be minimized.

Thirdly, in the process of planning, the course developer should try to create writing tasks that require simpler procedures and shorter length. The result of the study shows that some students were confused by the complexity of Task 3 (long report) and the substantial workload attached to the task. In fact as the instructor of the course, I admit that the writing required in Task 3 was long and repetitive. Students had to complete and comment on many drafts before finalizing their work. This might generate the negative feeling towards the online learning mode and account for their dissatisfaction over the course.

Moreover, inter- and intra-group co-operation should be strengthened. In the present study, the online writing environment provided a new avenue for students to receive feedback from peers; however, for the sake of management, students could only receive comments from their group members. As the groups were of mixed abilities here, some of the high-ability students commented that their group mates could not give them useful comments for improving their work. This may account for the low ratings they gave for the usefulness of peer help and the negative comments they made for the effectiveness of online collaboration. In the interview, a student even suggested 'putting the students of high ability in one group and the poor ones can be mixed with average ones'. However, this practice may generate the inferior feelings of the weaker students in the class and they may not benefit much if they only work with those of similar level. A possible way of tackling this problem is to incorporate inter-group co-operation in the writing process, so that students can receive input from other people other than their own group members. This corresponds with the suggestions made by the peer observer of the study:

A possible incentive for students to collaborate more online is to allow inter-group interactions and comments.

One area for further investigation is how to foster meaningful exchanges among groups of mixed English abilities.

In addition to the provision of opportunities for students to have an expanded audience, it is also important to strengthen intra-group co-operation. The study shows that the co-operation varied among groups. Some of them enjoyed their co-operation a lot while others did not. As reflected in the interview and reflective summaries, some of the students pointed out that they got irresponsible members who did not observe the deadlines or submit their work. To ensure that there is a smooth running of the system and that everyone in the group works and contributes, it is suggested that a more complete penalty and reward system should be introduced. This is also proposed by the peer observer in her report:

In relation to the problem of students not adhering to deadlines, a penalty can be imposed on those who submitted their work.

Furthermore, the major technological component of the course - email - should be improved. The user-friendliness of the technology employed in an online course can be a crucial factor contributing to students' positive attitudes towards the effectiveness of the course. In the interview and reflective summaries, some of the students expressed their dissatisfaction over the use of the email system of the WebCT platform chosen for this online writing course, and this could be a limiting factor in their interaction. It is thus suggested that the existing email system be able to:

- generate group distribution lists so as to provide ease of use for senders

- $\quad$ show the correct sending and receiving time of messages (i.e. the local time, not the US time, as at present)

- provide sorting functions so that messages can be sorted according to senders, receiving time or subjects

\section{Conclusion}

As the study draws its data from only a small group of learners, it does not claim much generalizability. The goal of the investigation reported here is to describe the process, results and participants' feelings about this particular online writing course. The results of this report attempt only to stimulate thinking by researchers into how a more appropriate application of online writing courses might be developed for the tertiary levels of Hong Kong.

\section{References}

Anderson, D. (2002). Interfacing email tutoring: Shaping an emergent literate practice. Computers and Composition. 19, 
71-87.

Andrewartha, G. \& Wilmot, S. (2001). Can multimedia meet tertiary educational needs better than the conventional lecture? A case study. Australian Journal of Educational Technology, 17(1), 1-20. Retrieved on September 7, 2005 from http://www.ascilite.org.au/ajet/ajet17/andrewartha.html

Berkow, P. (2001). Telecourse faculty guide for use with English composition: Writing for an audience. The Annenberg/CPB Telecourse. McGraw-Hill Online Learning Center. Retrieved on May 16, 2006 from http:/www.mhhe.com/socscience/english/annenberg/chap14.htm

Bloch, J. (2004). Second language cyber rhetoric: A study of Chinese L2 writers in an online usenet group. Language Learning \& Technology, 8 (3). Retrieved on April 28, 2006 from http://1lt.msu.edu/vol8num3/bloch/default.html

Bloom, B. S. (1956). Taxonomy of Educational Objectives: The Classification of Educational Goals. New York: Longman.

Bruffee, K. A. (1993). Collaborative learning: Higher education, interdependence, and the authority of knowledge. Baltimore and London: The Johns Hopkins University Press.

Cantrell, A. (2003). Crossing institutional boundaries: Defining the collaborative project. In M. Clayton, A. Cantrell, R. Legg. \& J. Lumpkins (eds.), Collaborative Teaching, Collaborative Learning: Expanding Communities of Writing Teachers and Students Cross Institutional Boundaries. KAIROS, 8(1). Retrieved on December 21, 2005 from http://english.ttu.edu/kairos/8.1/features/clayton/cantrell_paper.htm

Chenoweth, A. (1987). The need to teach rewriting. ELT Journal, 41(1). Retrieved on October 4, 2006 from http://eltj.oxfordjournals.org/content/vol41/issue1/index.dtl

Cicognani, A. (2000). Concept mapping as a collaborative tool for enhanced online learning. Education Technology \& Society, 3(3). Retrieved on December 21, 2005 from http://www.ifets.info/journals/3_3/b01.html

Crank, V. (2002). Asynchronous electronic peer response in a hybrid basic writing classroom. Retrieved on April 18, 2005 from www.ncte.org/pdfs/subscribers-only/tetyc/0302-dec02/TE0302Asynchronous.pdf

Cresswell, A. (2000). Self-monitoring in student writing: Developing learner responsibility. ELT Journal, 54(3). Retrieved on January 16, 2006 from http://eltj.oxfordjournals.org/archive/

DiGiovanni, E. \& Nagaswami, G. (2001). Online peer review: An alternative to face-to-face? ELT Journal, 55(3), 263-272. Retrieved on April 12, 2006 from http://eltj.oxfordjournals.org/cgi/reprint/55/3/263

Esnawy, S. (2004). Combining in-class and online ESP writing. IATEFL Poland Computer Special Interest Group Journal, 4 (3). Retrieved on April 10, 2006 from http://www.iatefl.org.pl/call/j_article18.htm

Ewing, J. \& Miller, D. (2002). A framework for evaluating computer supported collaborative learning. Educational Technology \& Society, 5(1). Retrieved on December 21, 2005 from http://www.ifets.info/

Ferris, D. (2003). Responding to writing. In B. Kroll (ed.), Exploring the dynamics of second language writing (pp.119-140). NY: CUP.

Greenfield, R. (2003, January). Collaborative email exchange for teaching secondary ESL: A case study in Hong Kong. Language Learning and Technology, 7(1), 46-70.

Hannafin, M. J. \& Hill, J. R. (2002). Epistemology and the design of learning environments. In R. A. Reiser \& J. V. Dempsey (eds.), Trends and issues in instructional design and technology (pp. 70-82). Upper Saddle River, NJ: Merrill.

Ho, C. (2000, December). Developing intercultural awareness and writing skills through email exchange. The Internet TESL Journal, 6(12). Retrieved on July 16, 2005 from http://iteslj.org

Järvelä, S., Hakkarainen, K., Lipponen, L. \& Lehtinen, E. (2000). Creating computer supported collaborative learning in Finnish schools: Research perspectives on sociocognitive effects. Journal of Continuing Engineering Education and Lifelong Learning, 10(2), 1-10.

Johnson, D.W., Johnson, R. T., \& Holubec, E. J. (1990). Circle of Learning. Edina, MN: Interaction Book Co.

Jor, G. (2000). Electronic collaboration across cultures in a web-based project for English Writing instruction. Paper presented at the Southeast Asian Ministers of Education Organization (SEAMO) Regional Language Centre, $35^{\text {th }}$ RELC International Seminar, Singapore.

Kraut, R., Kiesler, S., Boneva, B., Cummings, J., Helgeson, V. \& Crawford, A. (2002). Internet paradox revisited. Journal of Social Issues, 58(1). 49-74.

Krizan, A. C., Merrier, P. \& Jones, C. L. (2005). Business Communication. Ohio: South-Western College Publisher.

Lee, Y. H. \& Chen, N. S. (2000). Group composition methods for co-operative learning in web-based instructional 
systems. Proceedings of the $8^{\text {th }}$ International Conference on Computers in Education/International Conference on Computer-Assisted Instruction, 2000, 1538-1548.

McKenna, K., Green, A. \& Gleason, M. (2002). Relationship formation on the Internet: What's the big attraction? Journal of Social Issues, 58(1), 9-31.

Mendonça, C. \& Johnson, K. E. (1994). Peer review negotiations: Revision activities in ESL writing instruction. TESOL Quarterly, 28(4). 745-769.

Morris, J. L. (2001, October). The technology revolution. Retrieved on April 18, 2005 from http://www.uvm.edu/ jmorris/comps2.html

Piaget, J. (1928). The judgment and reasoning in children. London: Routledge \& Kegan.

Rizk, S. (2001). The effectiveness of online writing collaboration on EFL college student. Retrieved on May 29, 2006 from http://www.sabri.org/EDTECH-01/Study.htm

Rollinson, P. (2005). Using peer feedback in the ESL writing class. ELT Journal, 59 (1). Retrieved on December 21, 2005 from http://eltj.oxfordjournals.org/content/vol59/issue1/index.dtl

Slavin, R. E. (1996). Research on co-operative learning and achievement: What we know, what we need to know. Contemporary Education Psychology, 21, 43-69.

$\mathrm{Su}$, J., Chen, W., Chen, F. \& Tsai, Y. (2000). The project-based co-operative learning on Internet-A case study on Geology Education. Proceedings of the $8^{\text {th }}$ International Conference on Computers in Education/International Conference on Computer-Assisted Instruction, 2000, 303-308.

Tannacito, T. (2001). Teaching professional writing online with electronic peer response. KAIROS, 6 (2). Retrieved on April 24, 2006 from http://english.ttu.edu/kairos/6.2/coverweb/de/tannacito/Index.htm

Tsui, A. B. \& Ng, M. (2000). Do secondary L2 writers benefit from peer comments? Journal of Second Language Writing, 9, 147-170.

Tuzi, F. (2004). The impact of e-feedback on the revisions of L2 writers in an academic writing course. Computers and Composition, 21(2). Retrieved on $\quad$ April $\quad 19, \quad 2006$ from http://www.sciencedirect.com/science?_ob=MImg\&_imagekey=B6W49-4C7J8B6-4-5\&_cdi=6537\&_user=28301\&_ori $\mathrm{g}=$ browse\&_coverDate $=06 \% 2 \mathrm{~F} 30 \% 2 \mathrm{~F} 2004 \& \_\mathrm{sk}=999789997 \& v i e w=\mathrm{c} \& w \mathrm{chp}=\mathrm{dGLbVzz}-\mathrm{zSkWA} \& \mathrm{md} 5=3 \mathrm{f} 2 \mathrm{edcaaa} 5 \mathrm{da}$ 54b06c269726b418a443\&ie=/sdarticle.pdf

Valdez, G. (2005). Critical Issue: Technology: A Catalyst for Teaching and Learning in the Classroom. North Central Regional Educational Laboratory. Retrieved on January 16, 2006 from http:/www.ncrel.org/sdrs/areas/issues/methods/technlgy/te600.htm

Vygotsky, L. S. (1978). Mind in Society: The Development of Higher Psychological Processes. Cambridge, MA.: Harvard University Press.

Vygotsky, L. S. (1986). Thought and Language. Cambridge, MA: MIT Press.

Wellman, B., Quan-Hasse, A., Witte, J. \& Hampton, K. (2001). Does the Internet increase, decrease, or supplement social capital? Social networks, participation and community commitment. American Behavioral Scientist, 45(3), 436-455.

Williams, J. G. (2003). Providing feedback on ESL students' written assignments. The Internet TESL Journal, 4(10). Retrieved on December 21, 2005 from http://iteslj.org

Xun, G., Yamashiro, K. A. \& Lee, J. (2000). Pre-class planning to scaffold students for online collaborative learning activities. Education Technology \& Society, 3(3). Retrieved on December 21, 2005 from http://www.ifets.info/ 
Table 1

\begin{tabular}{|c|c|c|}
\hline \multirow{2}{*}{ Student } & \multicolumn{2}{|l|}{ Comments } \\
\hline & Task 1(Short report) & Task 3 (Long report) \\
\hline R-S17 & $\begin{array}{l}\text { Comments from them [peers] are useful for } \\
\text { me to improve my work and know more } \\
\text { about what mistakes I have made. I have } \\
\text { learnt a lot on this assignment with the help } \\
\text { of my members. }\end{array}$ & $\begin{array}{l}\text { I would rather prefer the traditional method } \\
\text { for doing this report because it is not } \\
\text { troublesome and each of us can concentrate } \\
\text { on our responsible part. }\end{array}$ \\
\hline $\mathrm{R}-\mathrm{S} 30$ & $\begin{array}{l}\text { In general, the online English lessons is } \\
\text { quite good and useful to me...the online } \\
\text { learning is interesting because we can do } \\
\text { tasks online, convenient to me, save time. }\end{array}$ & $\begin{array}{l}\ldots \text { the process of writing long report on } \\
\text { WebCT is complex because the steps are so } \\
\text { many. }\end{array}$ \\
\hline
\end{tabular}

Table 2

\begin{tabular}{|l|l|l|l|l|l|}
\hline Comments & $\begin{array}{l}\text { Strongly } \\
\text { agree } \\
\text { +agree }\end{array}$ & $\begin{array}{l}\text { Neutral/ } \\
\text { uncertain }\end{array}$ & $\begin{array}{l}\text { Strongly } \\
\text { disagree } \\
\text { +disagree }\end{array}$ & $\begin{array}{l}\text { Mean } \\
\text { scores }\end{array}$ & SD \\
\hline $\begin{array}{l}\text { \#A. Peer responses are useful for } \\
\text { correcting my work. }\end{array}$ & $71.9 \%$ & $25 \%$ & $3.1 \%$ & 3.84 & 0.71 \\
\hline $\begin{array}{l}\text { \#B. Feedback from peers on my work is } \\
\text { useful to the improvement of my writing } \\
\text { skills. }\end{array}$ & $71.9 \%$ & $25 \%$ & $3.1 \%$ & 4.03 & 0.85 \\
\hline $\begin{array}{l}\text { \#C. I found the comments of other } \\
\text { members useful. }\end{array}$ & $50 \%$ & $40.6 \%$ & $9.4 \%$ & 3.56 & 0.86 \\
\hline
\end{tabular}




\section{Appendix}

Summary of responses to the post-course questionnaire survey

Total responses: 34 (2 students were absent on the day of evaluation)

A. Results in percentages

\begin{tabular}{|c|c|c|c|c|c|}
\hline & $\begin{array}{l}\text { Strongly } \\
\text { Disagree }\end{array}$ & & & & $\begin{array}{l}\text { Strongly } \\
\text { Agree }\end{array}$ \\
\hline & 1 & 2 & 3 & 4 & 5 \\
\hline \multicolumn{6}{|l|}{ General Issues } \\
\hline $\begin{array}{l}\text { 1. I was given a good introduction on the writing } \\
\text { process before starting tasks. }\end{array}$ & 0.0 & 6.3 & 18.8 & 59.4 & 15.6 \\
\hline $\begin{array}{l}2 . \quad \text { I understood clearly the requirements of the tasks } \\
\text { before starting the task. }\end{array}$ & 0.0 & 0.0 & 34.4 & 40.6 & 25.0 \\
\hline $\begin{array}{l}\text { 3. I was able to use the email system (provided by the } \\
\text { WebCT platform) effectively for completing the tasks. }\end{array}$ & 3.1 & 0.0 & 15.6 & 34.4 & 46.9 \\
\hline 4. The support with this online course was sufficient. & 0.0 & 0.0 & 40.6 & 50.0 & 9.4 \\
\hline $\begin{array}{l}\text { 5. The design of Task } 1 \text { (short report) familiarized me } \\
\text { with the operation of the online writing process. }\end{array}$ & 0.0 & 3.1 & 25.0 & 56.3 & 15.6 \\
\hline $\begin{array}{l}\text { 6. The design of Task } 2 \text { (minutes) familiarized me with } \\
\text { the concept of online collaboration. }\end{array}$ & 0.0 & 0.0 & 40.6 & 53.1 & 6.3 \\
\hline $\begin{array}{l}\text { 7. The design of Task } 3 \text { (long report) consolidated my } \\
\text { skills in the use of online collaboration in English writing. }\end{array}$ & 0.0 & 6.3 & 34.4 & 50.0 & 9.4 \\
\hline $\begin{array}{l}\text { 8. The design of the course content was useful to my } \\
\text { learning. }\end{array}$ & 0.0 & 3.1 & 34.4 & 43.8 & 18.8 \\
\hline $\begin{array}{l}\text { 9. The use of the email system was helpful to my } \\
\text { interaction with my classmates. }\end{array}$ & 0.0 & 6.3 & 21.9 & 50.0 & 21.9 \\
\hline 10. Clear timelines and due dates were given. & 0.0 & 3.1 & 28.1 & 25.0 & 43.8 \\
\hline 11. It was good that we could choose our groupings. & 0.0 & 6.3 & 28.1 & 37.5 & 28.1 \\
\hline \multicolumn{6}{|l|}{ Tasks } \\
\hline 12. Task 1 was suitable to our level. & 0.0 & 0.0 & 18.8 & 46.9 & 34.4 \\
\hline 13. Task 2 was suitable to our level. & 0.0 & 3.1 & 15.6 & 46.9 & 34.4 \\
\hline 14. Task 3 was suitable to our level. & 0.0 & 3.1 & 34.4 & 37.5 & 25.0 \\
\hline 15. I had sufficient time to finish task 1. & 0.0 & 3.1 & 28.1 & 50.0 & 18.8 \\
\hline 16. I had sufficient time to finish task 2. & 0.0 & 3.1 & 28.1 & 50.0 & 18.8 \\
\hline 17. I had sufficient time to finish task 3 . & 0.0 & 21.9 & 46.9 & 21.9 & 9.4 \\
\hline $\begin{array}{l}\text { 18. Having the online features made completing the } \\
\text { tasks easier. }\end{array}$ & 0.0 & 6.3 & 40.6 & 28.1 & 25.0 \\
\hline \multicolumn{6}{|l|}{ Online collaboration and peer help } \\
\hline $\begin{array}{l}\text { 19. Peer-to peer learning was highly encouraged by the } \\
\text { online learning mode. }\end{array}$ & 0.0 & 0.0 & 34.4 & 65.6 & 0.0 \\
\hline 20. I worked well with my group mates. & 0.0 & 0.0 & 40.6 & 40.6 & 18.8 \\
\hline 21. Collaboration was built in through the tasks & 0.0 & 0.0 & 31.3 & 56.3 & 12.5 \\
\hline 22. Collaboration was built in through the use of email. & 0.0 & 0.0 & 34.4 & 65.6 & 0.0 \\
\hline $\begin{array}{l}\text { 23. Online collaboration could help me be more aware } \\
\text { the sense of audience in the writing process. }\end{array}$ & 0.0 & 0.0 & 46.9 & 50.0 & 3.1 \\
\hline $\begin{array}{l}\text { 24. Online collaboration could help me be more aware } \\
\text { of the importance of revision in the writing process. }\end{array}$ & 0.0 & 3.1 & 31.3 & 59.4 & 6.3 \\
\hline
\end{tabular}




\begin{tabular}{|c|c|c|c|c|c|}
\hline $\begin{array}{l}\text { 25. Online collaboration motivates my interest in } \\
\text { writing. }\end{array}$ & 0.0 & 9.4 & 43.8 & 40.6 & 6.3 \\
\hline $\begin{array}{l}\text { 26. Online collaboration could reduce my stress of } \\
\text { writing. }\end{array}$ & 0.0 & 9.4 & 21.9 & 59.4 & 9.4 \\
\hline 27. Peer responses were useful for correcting my work. & 0.0 & 3.1 & 25.0 & 56.3 & 15.6 \\
\hline \multirow{2}{*}{ Percentage $\%$} & $\begin{array}{l}\text { Strongly } \\
\text { Disagree }\end{array}$ & & & & $\begin{array}{l}\text { Strongly } \\
\text { Agree }\end{array}$ \\
\hline & 1 & 2 & 3 & 4 & 5 \\
\hline $\begin{array}{l}\text { 28. Feedback from peers on my work was useful to the } \\
\text { improvement of my writing skills. }\end{array}$ & 0.0 & 3.1 & 25.0 & 37.5 & 34.4 \\
\hline $\begin{array}{l}\text { 29. I felt comfortable discussing the task with my group } \\
\text { mates. }\end{array}$ & 0.0 & 6.3 & 34.4 & 43.8 & 15.6 \\
\hline 30. I found my interaction with my peers is valuable. & 0.0 & 3.1 & 37.5 & 40.6 & 18.8 \\
\hline $\begin{array}{l}\text { 31. I could give useful comments to other members on } \\
\text { their work. }\end{array}$ & 3.1 & 9.4 & 34.4 & 37.5 & 15.6 \\
\hline 32. I found the comments of other members useful. & 0.0 & 9.4 & 40.6 & 34.4 & 15.6 \\
\hline \multicolumn{6}{|l|}{ General opinions } \\
\hline 33. I like doing the English writing tasks online. & 0.0 & 12.5 & 28.1 & 53.1 & 6.3 \\
\hline 34. I enjoyed working with peers in the writing tasks. & 3.1 & 6.3 & 43.8 & 34.4 & 12.5 \\
\hline $\begin{array}{l}35 . \quad \text { I felt comfortable taking part in the group writing } \\
\text { tasks. }\end{array}$ & 0.0 & 0.0 & 53.1 & 34.4 & 12.5 \\
\hline $\begin{array}{l}\text { 36. It was easy to learn how to participate in the group } \\
\text { writing tasks. }\end{array}$ & 0.0 & 0.0 & 28.1 & 62.5 & 9.4 \\
\hline $\begin{array}{l}\text { 37. I enjoy the online writing lessons more than the } \\
\text { traditional writing ones. }\end{array}$ & 0.0 & 9.4 & 25.0 & 43.8 & 21.9 \\
\hline $\begin{array}{l}\text { 38. I believe my writing skills have improved using this } \\
\text { online course. }\end{array}$ & 3.1 & 3.1 & 50.0 & 37.5 & 6.3 \\
\hline 39. My confidence in using computers has increased. & 3.1 & 6.3 & 37.5 & 34.4 & 18.8 \\
\hline $\begin{array}{l}\text { 40. It was easier to discuss the tasks online than } \\
\text { face-to-face. }\end{array}$ & 6.3 & 31.3 & 37.5 & 18.8 & 6.3 \\
\hline $\begin{array}{l}\text { 41. I have learned how to be a more effective writer in } \\
\text { this course. }\end{array}$ & 0.0 & 12.5 & 37.5 & 46.9 & 3.1 \\
\hline 42. Overall, I am satisfied with the course. & 0.0 & 0.0 & 34.4 & 56.3 & 9.4 \\
\hline
\end{tabular}

